\title{
中國傳統的整體觀的思维模式對 意義與神聖價值的拯救
}

蔡 昱

讀了傑佛瑞 ·彼索普教授的很有啟發性的文章——從 “生 物醫學模式”到“生物社會心理精神醫學模式”一西方醫學史 的教訓〉(Bishop，2015), 文中介紹了美國醫學經歷的幾次變革。 其中, 兩次醫學模式的改革用心良苦, 卻都沒有成功, 其結果只 是科學主義侵入了越來越多的人類生命與健康領域。這和我們近 年來觀察到的恩格爾模式傳入中國所遭遇的壏加處境是相符合 的一一它既存在推廣應用中的操作困境, 也沒能減緩醫療異化和 醫德下滑。

西方自啟蒙運動以來本質上經歷的是一場世俗化的進程。一般 認為, 啟蒙運動的綱領之一是現代理性主義, 但其實質卻是世俗 的工具理性主義。啟蒙思想家在揭露基督教上至教皇下至神甫教 士的不擇手段斂財奢靡、批判基督教的偶像崇拜的同時, 也將作 為神聖價值而整合在中世紀基督教神學中的希臘哲學中的理性精 神（指思辨理性）、希伯來的宗教精神（指宗教倫理化）和羅馬 的法治精神 (法指自然律) 拋棄了。在世俗化過程中, 理性不再 為神聖目的服務, 而是為世俗目的服務; 工具理性也戰勝了思辨 理性, 滲透到生活的各個方面一一理性成了征服自然的工具、成 了控制社會的工具、成了考量自我效用最大化的工具, 當然, 也

蔡 昱, 雲南財經大學法學院哲學博士、教授, 中國昆明, 郵編：650221。

《中外醫學哲學》XIII:2 (2015 年) : 頁 123-125。

(C) Copyright 2015 by Global Scholarly Publications. 
成了應對人自身健康問題的工具。實際上, 工具理性只是應用在 科學和技術領域的思維定勢, 把它作為普遍的價值標準是新的教 條主義。

在西方醫學中大行其道的工具理性是一種還原論的思維方 法, 它還是一種空間式的思維方式。它將人的生命整體不斷分割 還原, 成為相互分離的系統, 再還原成相互分離的器官、組織、 細胞。它將這些分割後的生命要素並置於空間中, 還天真地認為 這樣的 “零部件” 組合起來便是可以 “運轉自如” 的人了。而在 這樣的還原過程中, 也失去了在人的整體層面上才得以向我們敞 開的“意義”，丢失了那些在傳統醫療中曾經令人熱淚盈眶的神 聖價值。這也是西方的醫療模式改革失敗的原因一一還原論的思 維模式帶來的宿命。也就是説, 意義和神聖價值是需要在整體和 整體性的思維模式中才可能被拯救的。

與西醫的機械唯物主義的還原論思維不同，中醫和中國哲學 為基礎的儒家生命倫理學 (如范瑞平教授創立的重構主義的儒家 生命倫理學）的思考方式是整體性的。這種思維方法將被分析物 視為相互聯繫著的部分, 它們仍是有機的整體。因此, 中醫從不 將人的生物存在、社會存在、心理存在和精神存在視為相互分離 的系統, 而將它們看作是作為部分而相互聯繫著的有機整體。中 醫也認為每一生命層面或身體的每一部份都能反映生命整體狀 況，同時，對任何一部分的治療都離不開對整體的協調，離不開 對整體功能的理順; 同樣, 儒家的生命倫理學並沒有將人的醫學 放到機械唯物主義的參照框架中去考量, 而是放在辯證的人文主 義的參照框架中, 這是一種不妥協的現實主義和合理的天道和仁 愛信仰的混合體。在儒家生命倫理學的整體關聯的思維模式下， 醫療模式的進步不應該是把既定的生物範疇與既定的社會領域、 心理領域與精神領域相分離, 並分別注重這四個領域。合理的醫 學模式應該以病人是存在於這四個領域的整體為著眼點的。與此 同時, 在儒家生命倫理的關照下, 人的人格除非從整體上來觀察, 
除非了解其生物、心理、社會、精神的狀況和需要的全貌, 是不 可能認識病人在情緒與精神上的紊亂的。同理, 將人的精神存在 和心理存在的研究與哲學和倫理方面的問題分離, 也是得不到準 確答案的。因此, 在儒家生命倫理學看來, 彼索普教授文中所提 到的心理學的量表在 “生物社會心理精神醫學模式” 中的應用就 如同 “心理人”、“經濟人”的假説一樣不切實際, 但這也是工 具理性的另一典型特徵——對質料性價值的數量化衡量。

彼索普教授在文章最後的提醒是非常誠摰的。中國需要如重 構主義的儒家生命倫理學這樣的 “摒棄了妖魔化的儒家, 告別殖 民化的儒家，而構建本真的當代儒家，即面對當代的社會現實， 綜合領會和把握儒家的核心主張, 通過分析比較的方法找到適宜 的當代語言進行表述, 為當代政策與制度改革提供直接的、具體 的儒家資源”（范瑞平，2010）的紮根於中國自己的文化傳統的 生命倫理學。

\section{參考文獻}

范瑞平：《當代儒家生命倫理學》, 北京: 北京大學出版社, $2010 \circ \mathrm{FAN}$ Ruiping. Contemporary Confucian Bioethics (Beijing: Peking University Press, 2010).

傑佛瑞・彼索普：〈從 “生物醫學模式” 到 “生物社會心理精神醫學模 式”一西方醫學史的教訓〉, 載范瑞平編, 《中外醫學哲學》, 2015 年, 第 13 卷, 第 2 期, 頁 89-118。Bishop, Jeffrey P. “From Biomedicine to Biopsychosociospiritual Medicine: A Lesson in the History of Medicine in the West," International Journal of Chinese \& Comparative Philosophy of Medicine, edited by FAN Ruiping, 13:2(2015), pp.89-118. 